\title{
Progesterone Downregulates Oestrogen-Induced Expression of CFTR and SLC26A6 Proteins and mRNA in Rats' Uteri
}

\author{
K. Gholami, ${ }^{1}$ S. Muniandy, ${ }^{1}$ and N. Salleh ${ }^{2}$ \\ ${ }^{1}$ Department of Molecular Medicine, Faculty of Medicine, University of Malaya, 50603 Kuala Lumpur, Malaysia \\ ${ }^{2}$ Department of Physiology, Faculty of Medicine, University of Malaya, 50603 Kuala Lumpur, Malaysia
}

Correspondence should be addressed to N. Salleh, naguib.salleh@yahoo.com.my

Received 13 September 2012; Accepted 23 October 2012

Academic Editor: Anton M. Jetten

Copyright ( $) 2012$ K. Gholami et al. This is an open access article distributed under the Creative Commons Attribution License, which permits unrestricted use, distribution, and reproduction in any medium, provided the original work is properly cited.

\begin{abstract}
Under progesterone $(\mathrm{P})$ dominance, fluid loss assists uterine closure which is associated with $\mathrm{pH}$ reduction. We hypothesize that $\mathrm{P}$ inhibits uterine fluid secretion and $\mathrm{HCO}_{3}{ }^{-}$transport. Aim. to investigate the expression of Cystic Fibrosis Transmembrane Regulator (CFTR) and $\mathrm{Cl}^{-} / \mathrm{HCO}_{3}{ }^{-}$exchanger (SLC26A6) under P effect. Method. Uteri from ovariectomized steroid replaced and intact rats at different stages of oestrous cycle were analyzed for changes in protein and mRNA expressions. Results. P inhibits CFTR and SLC26A6 proteins and mRNA expression while oestrogen (E) causes vice versa. E treatment followed by $\mathrm{P}$ causes a reduction in these transporters' mRNA and protein. Similar changes occur throughout the oestrous cycle; that is, CFTR mRNA expression was high at proestrus while SLC26A6 mRNA and protein expressions were increased at proestrus and estrus. At diestrus, however, the expression of these transporters' protein and mRNA was reduced. Conclusion. Inhibition of CFTR and SLC26A6 expressions may explain the reduced fluid volume and $\mathrm{pH}$ under P-mediated effect.
\end{abstract}

\section{Introduction}

Implantation is a complex process that requires synchronization between the events that occur in the uterus and that of the embryo [1]. Uterine events are under the influence of sex steroids which include alteration in the luminal fluid volume, $\mathrm{pH}$, metabolites, and ionic compositions [2]. Under the influence of oestrogen (E), there is an obvious fluid accumulation, while a reduction of fluid volume has been reported under progesterone $(\mathrm{P})[3,4]$. While fluid accumulation is thought to be important for sperm and embryo transport, fluid loss has been proposed to assist closure of the uterine lumen, sandwiching the blastocyst between the two opposing walls of the uterus, prior to the attachment phase of implantation $[5,6]$.

The mechanisms underlying fluid loss under $\mathrm{P}$ dominance are still matters of debate. These were thought to be due to an increase in the expression of epithelial sodium channel (ENaC) and aquaporin ( $\mathrm{AQP})$ under P stimulation, resulting in fluid imbibitions secondary to $\mathrm{Na}^{+}$movements (via ENaC) [7-9]. On the other hand, reduced fluid secretion could also be the reason for volume reduction under progesterone-mediated effect, which could be mediated via inhibition of CFTR (as CFTR has been linked to fluid secretion). Fluid that accumulates under E stimulation may escape through the cervix and together with the inhibition of fluid secretion, resulting in the observed reduction in fluid volume under progesterone-mediated effect $[8,10]$.

There is a close relationship between the uterine luminal fluid $\mathrm{pH}$ and volume changes. Volume increase is often associated with $\mathrm{pH}$ increase under $\mathrm{E}$ dominance, while a reduction in volume is associated with a parallel $\mathrm{pH}$ reduction under $\mathrm{P}$ dominant [11]. An increase in the $\mathrm{pH}$ has been reported to be due to $\mathrm{HCO}_{3}{ }^{-}$secretion, in which its level is the highest at the time of ovulation [12]. CFTR and $\mathrm{Cl}^{-} / \mathrm{HCO}_{3}{ }^{-}$exchanger, the two channels that are responsible for $\mathrm{HCO}_{3}{ }^{-}$secretion, have been shown to be upregulated by $\mathrm{E}$ [13]. A documented $\mathrm{pH}$ reduction under $\mathrm{P}$ effect by direct luminal $\mathrm{pH}$ measurement [11] suggests either an increased secretion of proton or an inhibition of $\mathrm{HCO}_{3}{ }^{-}$secretion via CFTR, and $\mathrm{Cl}^{-} / \mathrm{HCO}_{3}{ }^{-}$exchanger (SLC26A6) may occur under this condition. 
Secretion of $\mathrm{HCO}_{3}{ }^{-}$, which plays an important role in sperm capacitation,embryo development, and reducing the uterocervical mucus elasticity for sperm penetration $[6,14]$, has been reported to involve the basolaterally located sodium-proton exchanger (NHE), sodiumbicarbonate cotransporter (NBC) $[15,16]$, and the apically located CFTR and $\mathrm{Cl}^{-} / \mathrm{HCO}_{3}{ }^{-}$exchanger (SLC26A6) [17]. In addition, carbonic anhydrase is also responsible for the intracellular $\mathrm{HCO}_{3}{ }^{-}$generation $[14,18]$. The involvement of CFTR in $\mathrm{HCO}_{3}{ }^{-}$secretion has been reported in the secretory epithelia [19], whereby its mutation resulted in an impaired $\mathrm{HCO}_{3}{ }^{-}$secretion as seen in Cystic Fibrosis. $\mathrm{Cl}^{-} / \mathrm{HCO}_{3}{ }^{-}$ exchanger, from SLC26A6 family, plays an important role in $\mathrm{HCO}_{3}{ }^{-}$secretion in some secretory epithelia such as the pancreatic duct, and its expression in the duodenum is under the influence of $\mathrm{E}[10,20]$.

We hypothesize that the observed reduction in the uterine fluid volume under $\mathrm{P}$ effect may occur via inhibition of CFTR-mediated increased in fluid secretion, while a parallel decrease in the $\mathrm{pH}$ could be due to a diminished $\mathrm{HCO}_{3}{ }^{-}$ secretion via inhibition of the apically located CFTR and $\mathrm{Cl}^{-} / \mathrm{HCO}_{3}{ }^{-}$exchanger. The aim of our study is to investigate the changes in mRNA and protein expression of both transporters under the influence of progesterone and to compare these effects under the presence of $\mathrm{E}$ in order to provide an alternative explanation for the common effects of $\mathrm{P}$ in reducing the uterine luminal fluid volume and $\mathrm{pH}$.

\section{Material and Methods}

2.1. Animals and Hormone Treatment. Adult female WKY rats, supplied by the Animal House, Faculty of Medicine, UM, were kept in a clean and well-ventilated animal lab which was maintained with a standard suitable environment of 12 hours light: dark cycle, room temperature kept at $\pm 25^{\circ} \mathrm{C}$, and a humidity of $30-70 \%$. The animals were fed with soy-free diet (Gold Coin Pellet) and tap water ad libitum. All experimental procedures were approved by the Faculty of Medicine Animal Care and Use Committee (ACUC), UM, with the ethics number 14/9/2009/FIS/NS. Ten days after ovariectomy, the rats were divided into seven groups which received the following treatment: $0.2 \mu \mathrm{g}, 20 \mu \mathrm{g}$, $50 \mu \mathrm{g}$ E for three consecutive days, $4 \mathrm{mg}$ P for three consecutive days, $0.2 \mu \mathrm{g}$ E for three consecutive days followed by $4 \mathrm{mg}$ $\mathrm{P}$ for another 3 days $(\mathrm{E}+\mathrm{P})$, and three days treatment with peanut oil as a control. Additionally, another group received $0.2 \mu \mathrm{g}$ E for 3 days followed by 3 days peanut oil ( $\mathrm{E}+$ vehicle) which acts as a control for the $\mathrm{E}+\mathrm{P}$ group. All drugs were dissolved in peanut oil (vehicle) and were administered via a subcutaneous injection behind the neck cuff. Twenty-four hours after the last injection, the rats were anesthetized and uterine tissues were collected for protein and mRNA analysis.

2.2. Oestrous Cycle Phases Identification. Vaginal secretion was collected with a plastic pipette filled with $10 \mu \mathrm{L}$ of normal saline $(\mathrm{NaCl} 0.9 \%)$ by inserting the tip of the pipette into the rat vagina, but not deeply to avoid cervical stimulation. Unstained material was placed onto a slide and was observed under a light microscope. The proportion of different cells was used to determine the oestrous cycle phases, in which round and nucleated cells are epithelial cells which define proestrus; irregular shapes without nuclei are the cornified cells that were observed during estrus; the little round cells are the leukocytes that characterize diestrus. At metestrus, however, three different kinds of cells could be identified [21]. Following steroid treatment or oestrous cycle phases identification, the rats were sacrificed by cervical dislocation. Uterine tissues were removed and placed into RNA-Later solution for real-time PCR or snap frozen in liquid nitrogen for Western blot analysis.

2.3. Protein Analysis by Western Blotting. Snap-frozen tissues were homogenized by sonication with PRO-PREP (Intron) extraction solution in the presence of protease inhibitors. The total cell protein was obtained by centrifugation at $13000 \mathrm{~g}$ for 15 minutes at $4^{\circ} \mathrm{C}$. After determination of the protein concentration, the same amount of protein was loaded onto 12\% SDS-PAGE. Protein was then transferred onto the PVDF membrane and the blot incubated with 5\% BSA for 90 minutes. The blot was then exposed to a primary antibody, at 1:1000 dilutions. CFTR and SLC26A6 goat polyclonal primary antibodies were obtained from Santa Cruz, USA. Following this, the blot was then incubated with HRP-conjugated secondary antibody and finally it was visualized by Optic 4C (Bio RAD). B-actin (Abcam) was used as a loading control. The photos of the blots were captured and gel documentation of the density of each band was determined using Image J software. The ratio of each band $/ \beta$ actin was considered as the expression level of the target protein.

2.4. mRNA Analysis by Real-Time PCR. RNA Later was used to maintain RNA integrity prior to extraction. RNA extraction was performed using Ribo pure kit from Ambion according the manufacturer's instruction, with TRI reagent. In this experiment, one-step real-time PCR was used to evaluate gene expression. TaqMan RNA-to-CT 1-Step Kit with total volume of $10 \mu \mathrm{L}$ per reaction was used. Reaction material included $5 \mu \mathrm{L}$ master mix, $0.225 \mu \mathrm{L}$ reverse transcriptase, $3.25 \mu \mathrm{L}$ water, and $1 \mu \mathrm{L}$ sample that contained $100 \mathrm{ng}$ total RNA. HPRT1 and GAPDH were used as endogenous controls. All experiments were done with 3 biological replicates. A PCR program included 15 minutes, $48^{\circ} \mathrm{C}$ reverse transcriptase, 10 minutes $95^{\circ} \mathrm{C}$ activation of Ampli Taq gold DNA polymerase, and 40 cycle denature at $95^{\circ} \mathrm{C}, 15$ seconds, and annealing at $60^{\circ} \mathrm{C}$ for 1 minutes. Denaturing and annealing were performed for 40 cycles. All TaqMan assays were purchased from Applied Biosystem, USA.

2.5. Statistical Analysis. Results were expressed as mean \pm SEM, and the $n$ value indicates the number of rats. Comparisons between groups of data were done by one-way ANOVA. $P$ value of less than 0.05 was considered to be statistically significant. Data assist v3 was used to analyze real-time PCR results and the band density in Western blot was quantified by Image J software. 


\section{Results}

3.1. CFTR mRNA and Protein Expression. In Figure 1, the level of CFTR mRNA was significantly reduced following $\mathrm{P}$ treatment as compared to $0.2 \mu \mathrm{g} \mathrm{E}$ and control. The inhibitory effect of P on CFTR mRNA expression could be seen in the group treated with $0.2 \mu \mathrm{g}$ E followed by $\mathrm{P}$, in which there was a 13-fold reduction in the mRNA level as compared to $0.2 \mu \mathrm{g} \mathrm{E}$ or $\mathrm{E}$ plus vehicle $(\mathrm{E}+\mathrm{V})$. Quantification of CFTR mRNA under different hormonal treatment has never been made previously, apart from semiquantitative evidence from immunohistochemistry [22]. We have also provided the first evidence of a dose-dependent increase in CFTR mRNA following E treatment.

The highest amount of CFTR mRNA was observed following treatment with $50 \mu \mathrm{g}$ E, which was 16-fold higher as compared to the control. Treatment with $0.2 \mu \mathrm{g}$ E resulted in a 12-fold increase in the CFTR mRNA level. Similar patterns of CFTR mRNA changes could be seen throughout the oestrus cycle. Cyclical changes in the pattern of CFTR mRNA have been previously reported in mice in which the level was the highest at estrus and the lowest at diestrus [8]. Our finding, however, indicates that CFTR mRNA was the highest at proestrus, with a 10 -fold increase, while at estrus, there was only 3 -fold increase in its expression. We were able to detect CFTR mRNA expression even at an earlier stage of the oestrous cycle than the previous report [8]. During diestrus stage, however, the mRNA level was noted to be the lowest with only a 1.5-fold increase as compared to the control.

Protein expression follows an almost similar pattern to the changes in mRNA (Figure $1(\mathrm{~b})$ ). $\mathrm{P}$ treatment resulted in decreased CFTR protein expression as compared to the control and $0.2 \mu \mathrm{g}$ E. There was a dose-dependent increase in the protein expression under $\mathrm{E}$, in which treatment with $50 \mu \mathrm{g} \mathrm{E}$ resulted in approximately two-times increase in protein expression as compared to $0.2 \mu \mathrm{g}$ E. As expected, E treatment followed by three days of $\mathrm{P}$ treatment $(\mathrm{E}+\mathrm{P})$ resulted in a reduction in the protein expression by about 1.5 times as compared to $0.2 \mu \mathrm{g}$ E or E plus vehicle $(\mathrm{E}+\mathrm{V})$.

The highest expression of CFTR protein was noted at proestrus and estrus which correlates with a high plasma $\mathrm{E}$ level. The amount expressed declined at metestrus, reaching the lowest at diestrus. This is consistent with increasing level of $\mathrm{P}$ in the circulation.

3.2. SLC26A6 mRNA and Protein Expression. In Figure 2, real-time PCR showed that the expression of SLC26A6 mRNA was under the influence of sex steroids (Figure 2(a)). Under P influence, SLC26A6 mRNA level was increased relative to the control. The mRNA expression under $\mathrm{P}$ was lower than $0.2 \mu \mathrm{g} \mathrm{E}(P<0.05)$. We have shown that there was a dose-dependent increase in the expression of SLC26A6 mRNA under E, ranging between 1.5 and 5-fold increase following treatment with $0.2 \mu \mathrm{g}$ E and $50 \mu \mathrm{g}$ E, respectively. Treatment with $\mathrm{E}$ followed by $\mathrm{P}(\mathrm{E}+\mathrm{P})$ resulted in a significant reduction in the mRNA level, which indicates that P acutely suppressed the expression of SLC26A6 mRNA induced by E. There was a significant reduction in SLC26A6
mRNA expression following treatment with $\mathrm{E}+\mathrm{P}$ as compared to $\mathrm{E}+$ vehicle $(\mathrm{V})(P<0.05)$.

Throughout the oestrous cycle, an increase in SLC26A6 mRNA expression by 3.2- and 3.5-fold could be seen at proestrus and estrus stages, respectively. The expression was, however, reduced at metestrus and sharply declined at diestrus $(P<0.05)$. These observations indicate that SLC26A6 mRNA expression was upregulated by E, while P downregulates its expression.

Western blot analysis of SLC26A6 protein showed similar changes to the mRNA. $\mathrm{P}$ resulted in a decrease in the expression of SLC26A6 protein as compared to the control $(P<0.05)$. A dose-dependent increase in protein expression was observed following $\mathrm{E}$ treatment. A 0.15 - to 0.2 -fold increase in SLC26A6 protein expression was seen following treatment with $0.2 \mu \mathrm{g} \mathrm{E}$, and $50 \mu \mathrm{g}$ E respectively. Administration of $\mathrm{P}$ after three days of treatment with $0.2 \mu \mathrm{g} \mathrm{E}$ did not result in a significant reduction in the expression of SLC26A6 protein as compared to $0.2 \mu \mathrm{g}$ E alone or E treatment followed by vehicle (a control group for $\mathrm{E}+\mathrm{P}$ ). The highest protein expression was observed at proestrus while the lowest expression could be seen at diestrus.

In general, the amount of CFTR mRNA was found to be three times greater than SLC26A6 mRNA at proestrus. At diestrus, however, the amount of both transporters' mRNAs was almost equal. P inhibition on CFTR mRNA was more pronounced than its inhibition on SLC26A6 mRNA expression in the same tissue under a similar hormonal condition.

\section{Discussion}

The actual mechanism involved in the control of uterine luminal fluid volume is still a matter of debate among reproductive biologists. The first evidence regarding the role of CFTR in uterine fluid volume regulation surfaced nearly 20 years ago when Rochwerger and Buchwald (1993) [23], using in situ hybridization and protein studies, reported that E stimulates uterine CFTR expression. Forskolin-stimulated $\mathrm{Cl}^{-}$permeability was observed at the apical membrane of the endometrial cells while in vitro primary cultures of rat uterine epithelial cells showed high levels of CFTR expression under E stimulation [24]. In contrast to oestrogen, Mularoni et al. (1995) [25], using a competitive RT-PCR technique, reported that CFTR mRNA level in the glandular epithelial cells of guinea-pig endometrium decreases upon treatment with oestradiol plus progesterone as compared to the treatment with oestradiol in an in vitro study. Apart from this limited observation, the actual effect of progesterone on uterine CFTR expression is still not fully elucidated. Our current study was undertaken to investigate the actual effect of progesterone treatment alone and the effect of progesterone following exposure to oestrogen on the mRNA and protein expression of CFTR as well as SLC26A6 in the uterine tissues in a rat model.

A complimentary finding by Chan et al. (2002) [8] indicates fluctuation in CFTR mRNA expression in adult female mouse reproductive tract at different phases of the oestrous cycle. In situ hybridization and semi-quantitative RT-PCR revealed abundant expression of CFTR mRNA in 


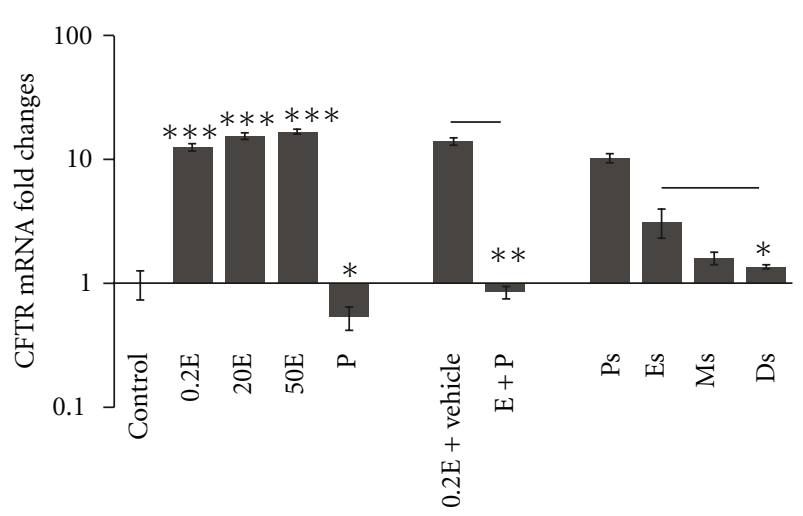

(a)

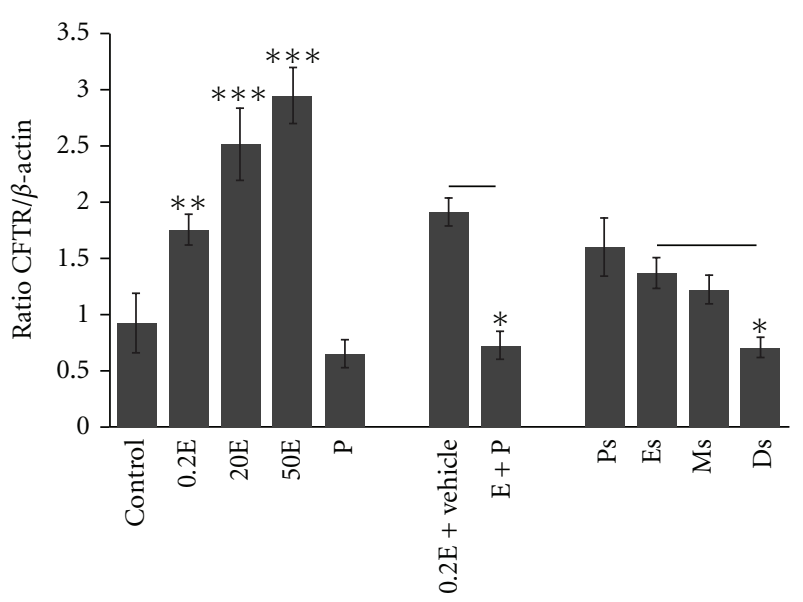

(b)

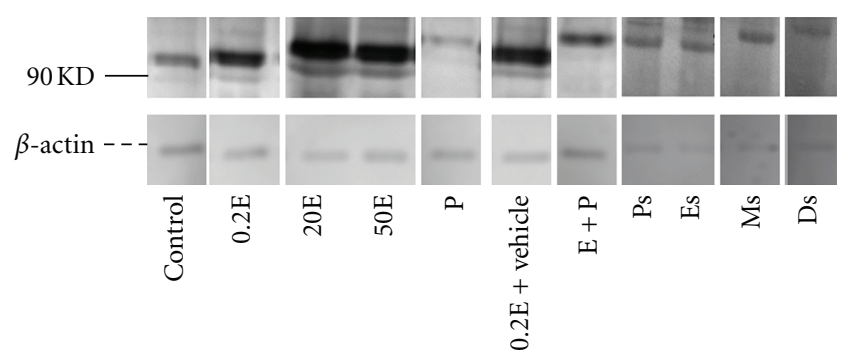

(c)

FIGURE 1: Real-time PCR (a) and Western blotting analysis (b) of total homogenate of the uterus; representative photo of western blots (c) of CFTR in ovariectomized rats and rats at different stages of the oestrous cycle. Results indicate that CFTR expression is oestrogen dependent. The photos as shown in (c) came from a same gel/blot that has been cut in order to arrange the different groups of treatment in sequence as to match the result in (a) and (b). Control: peanut oil, E: $0.2 \mu \mathrm{g}$ oestrogen, $20 \mathrm{E}: 20 \mu \mathrm{g}$ oestrogen, $50 \mathrm{E}: 50 \mu \mathrm{g}$ oestrogen, P: progesterone, E + vehicle: $0.2 \mu \mathrm{g}$ oestrogen + peanut oil E + P: $0.2 \mu \mathrm{g}$ oestrogen + progesterone. Ps: proestrus, Es: estrus, Ms: metestrus, Ds: diestrus: ${ }^{*} P<0.05$, ${ }^{* *} P<0.01,{ }^{* * *} P<0.001$.

the uterine epithelium at estrus but not at other stages of the cycle. In contrast to Chan et al. (2002) [8], our finding, however, indicates that CFTR mRNA expression is the highest at proestrus. These differences in the time of CFTR mRNA expression could probably be related to species difference, in which Chan et al. (2002) [8] conducted their study in mice in contrast to our rats' model. Yang et al. (2004) [26] studied CFTR expression in pregnant mice by RT-PCR, which showed a maximum CFTR expression at day 3 after-mating predominantly in the stromal cells. Salleh et al. (2005) [22] demonstrated by immunostaining that CFTR is highly expressed at the apical membrane of rat's endometrium and was up-regulated by $\mathrm{E}$. They further proposed that CFTR is involved in uterine $\mathrm{Cl}^{-}$and fluid secretion under E stimulation. Meanwhile, Nobuzane et al. (2008) [27] reported that treatment with raloxifene analogue induced CFTR expression in a study using RT-PCR.

An exact determination of the amount of mRNA is not possible by a traditional PCR, therefore real time PCR (as used in our study) is the best alternative that offers an accurate quantification of mRNA expression as little as a twofold increase [28]. We have precisely quantified the amount of CFTR mRNA expressed under different effect of sex steroids.
Our findings indicate that CFTR mRNA expression is highly increased following exogenous $\mathrm{E}$ administration and under a high level of endogenous E; therefore, CFTR could be the major anion channel expressed which may participate in the observed accumulation of uterine fluid under $\mathrm{E}$ dominance. In addition, the dose- dependent effect of $\mathrm{E}$ on CFTR mRNA expression could provide a fundamental basis for the observed excessive fluid accumulation under hyperestrogenic condition such as following consumption of oral contraceptive pills [22]. To the best of our knowledge, this is the first report on the acute suppression by progesterone on CFTR expression in vivo in steroid replaced ovariectomized rats as well as under a high endogenous $\mathrm{P}$ level, thus supporting the previous in vitro observation by Mularoni et al. (1995) [25]. Progesterone effect on CFTR expression could be mediated via genomic pathway possibly via CFTR gene suppression, apart from an indirect inhibition of CFTR activities via the activation of epithelial $\mathrm{Na}^{+}$channel $(\mathrm{ENaC})$ as $\mathrm{ENaC}$ has been shown to be a negative regulator of CFTR [29]. We need to further confirm this by administering a progesterone receptor blocker, mifepristone. Our study thus provides novel information that progesterone is responsible for suppression of CFTR expression in-vivo, which may explain 


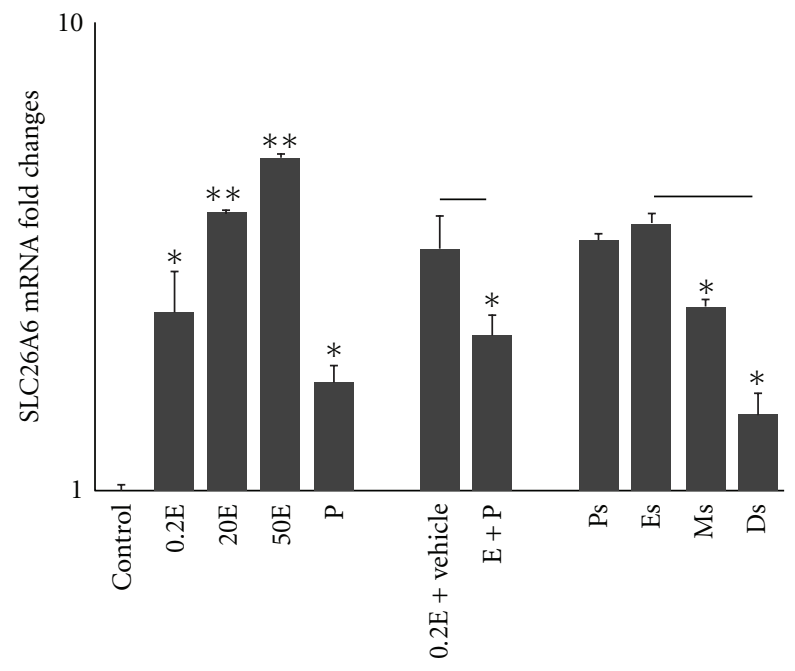

(a)

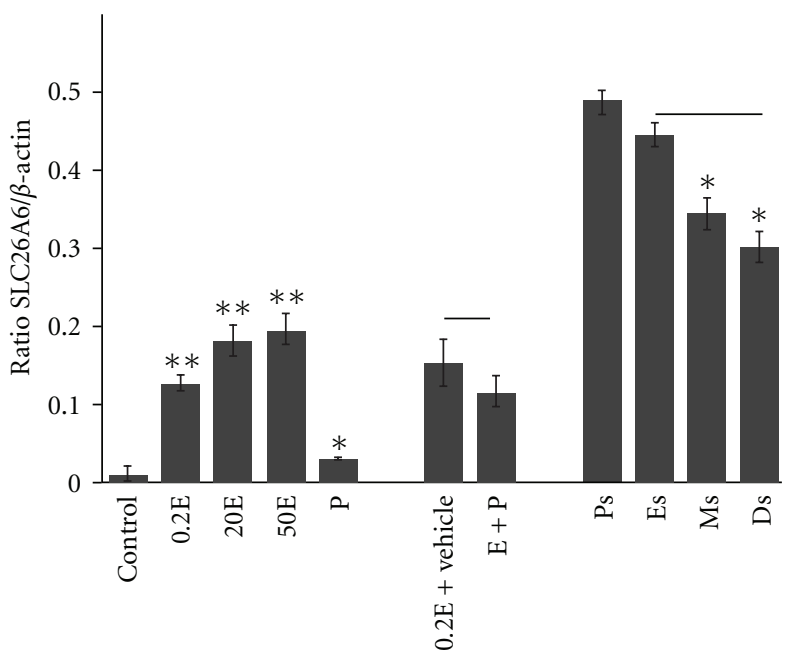

(b)

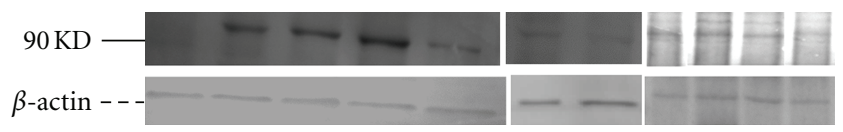

(c)

FIGURE 2: Real-time PCR quantitation (a), and Western blot analysis (b), and Western blot photo (c) of SLC26A6 in ovariectomized rats and rats at different stages of the oestrous cycle. SLC26A6 is from $\mathrm{Cl}^{-} / \mathrm{HCO}_{3}{ }^{-}$exchanger family that is upregulated by oestrogen and at Ps and Es stages of the oestrous cycle. Control: peanut oil., E: $0.2 \mu \mathrm{g}$ oestrogen, $20 \mathrm{E}: 20 \mu \mathrm{g}$ oestrogen, $50 \mathrm{E}: 50 \mu \mathrm{g}$ oestrogen, P: progesterone, E + vehicle: $0.2 \mu$ g oestrogen + peanut oil E + P: $0.2 \mu$ g oestrogen + progesterone. Ps: proestrus, Es: estrus, Ms: metestrus, Ds: diestrus: ${ }^{*} P<0.05$, $* * P<0.01, * * * P<0.001$.

the diminished fluid secretion under a P-mediated effect. This would complement ENaC-mediated fluid imbibition, contributing to fluid loss that initiates uterine closure.

Apart from being a $\mathrm{Cl}^{-}$channel, CFTR has also been reported to be involved in $\mathrm{HCO}_{3}^{-}$secretion. An increase in $\mathrm{HCO}_{3}{ }^{-}$secretion has been reported under E influence [13], in parallel with an increase in fluid secretion. E stimulation of $\mathrm{HCO}_{3}{ }^{-}$secretion has also been shown to occur in the duodenum via CFTR and $\mathrm{Cl}^{-} / \mathrm{HCO}_{3}{ }^{-}$exchanger [30], which is responsible for the lower prevalence of duodenal ulcer in premenopausal women [31]. In addition to E, genistein, a phytoestrogen, has also been reported to increase duodenal $\mathrm{HCO}_{3}{ }^{-}$secretion in a dose-dependent manner through stimulation of CFTR [32]. These observations support the notion that CFTR is the main $\mathrm{HCO}_{3}{ }^{-}$extruder under $\mathrm{E}$ effect. Uterine $\mathrm{HCO}_{3}{ }^{-}$secretion plays an important role in many reproductive events that have been described earlier.

The involvement of SLC26A6 in mediating uterine $\mathrm{HCO}_{3}{ }^{-}$secretion has received a lot of attention lately. The important role of this transporter in the uterus has been overlooked. While He et al. [13] has examined SLC26A6 protein expression in mice uteri which indicates a maximum expression of this protein under $\mathrm{E}$ dominance; its mRNA expression is, however, unknown. We have therefore provided novel information on the E-induced upregulation and P-induced downregulation of uterine SLC26A6 mRNA expression in vivo. In addition, we have also documented for the first time that SLC26A6 mRNA exhibits cyclical changes throughout the oestrous cycle, in which its expression is increased at proestrus and estrus and decreased at diestrus. The significance of this finding is unknown; however, we postulate that the increase in SLC26A6 expression under E influence may contribute to the alkalinity of uterine fluid via contributing to $\mathrm{HCO}_{3}{ }^{-}$secretion. The stoichiometry of $1 \mathrm{Cl}^{-}$ to $2 \mathrm{HCO}_{3}{ }^{-}$further assists in luminal $\mathrm{HCO}_{3}{ }^{-}$accumulation in exchange with $\mathrm{Cl}^{-}$, which needs to be recycled following its secretion through the CFTR. $\mathrm{Cl}^{-}$recycling may prevent excessive fluid secretion under $\mathrm{E}$ stimulation, which perhaps plays a role in a negative feedback control of uterine luminal fluid secretion.

Progesterone down-regulation of SLC26A6 resulted in a diminished $\mathrm{HCO}_{3}{ }^{-}$secretion and together with an increased $\mathrm{H}^{+}$secretion via the sodium-hydrogen exchanger (NHE) [11] initiates fluid loss from the uterine lumen. This would therefore complement $\mathrm{ENaC}$ in contributing to uterine fluid loss under progesterone effect in order to initiate the process leading to "uterine closure," sandwiching the embryo between the two opposing uterine walls. To the best of our knowledge, this study is the first to document the concomitant expressions of CFTR and SLC26A6 in the adult female rat's uterus and that both transporters mRNA and protein expression are under a common regulation by endogenous sex steroids. A precise regulation in these proteins and mRNAs expression would contribute to an accurate control of the uterine fluid volume and $\mathrm{pH}$ that are required for a successful implantation. 


\section{Conflict of Interests}

The authors wish to confirm that there is no known conflict of interests associated with this publication and there has been no significant financial support for this work that could have influenced its outcome.

\section{Acknowledgment}

This work is supported by UMRG and IPPP Grants from the University of Malaya, Kuala Lumpur, Malaysia.

\section{References}

[1] P. H. Kodaman and H. S. Taylor, "Hormonal regulation of implantation," Obstetrics and Gynecology Clinics of North America, vol. 31, no. 4, pp. 745-766, 2004.

[2] S. Bauersachs, S. E. Ulbrich, K. Gross et al., "Gene expression profiling of bovine endometrium during the oestrous cycle: detection of molecular pathways involved in functional changes," Journal of Molecular Endocrinology, vol. 34, no. 3, pp. 889-908, 2005.

[3] J. Aguilar and M. Reyley, "The uterine tubal fluid: secretion, composition and biological effects," Animal Reproduction, vol. 2, pp. 91-105, 2005.

[4] C. A. B. Clemetson, V. R. Mallikarjuneswara, M. M. Moshfeghi, J. J. Carr, and J. H. Wilds, "The effects of oestrogen and progesterone on the sodium and potassium concentrations of rat uterine fluid," Journal of Endocrinology, vol. 47, no. 3, pp. 309-319, 1970.

[5] L. Martin, C. A. Finn, and J. Carter, "Effects of progesterone and oestradiol-17 beta on the luminal epithelium of the mouse uterus," Journal of Reproduction and Fertility, vol. 21, no. 3, pp. 461-469, 1970.

[6] J. Hu and T. E. Spencer, "Carbonic anhydrase regulate endometrial gland development in the neonatal uterus," Biology of Reproduction, vol. 73, no. 1, pp. 131-138, 2005.

[7] L. A. Lindsay and C. R. Murphy, "Redistribution of aquaporins 1 and 5 in the rat uterus is dependent on progesterone: a study with light and electron microscopy," Reproduction, vol. 131, no. 2, pp. 369-378, 2006.

[8] L. N. Chan, L. L. Tsang, D. K. Rowlands et al., "Distribution and regulation of ENaC subunit and CFTR mRNA expression in murine female reproductive tract," Journal of Membrane Biology, vol. 185, no. 2, pp. 165-176, 2002.

[9] M. T. Skowronski, "Distribution and quantitative changes in amounts of aquaporin 1, 5 and 9 in the pig uterus during the estrous cycle and early pregnancy," Reproductive Biology and Endocrinology, vol. 8, article 109, 2010.

[10] Y. Wang, A. A. Soyombo, N. Shcheynikov et al., "Slc26a6 regulates CFTR activity in vivo to determine pancreatic duct $\mathrm{HCO}_{3}$ - secretion: relevance to cystic fibrosis," EMBO Journal, vol. 25, no. 21, pp. 5049-5057, 2006.

[11] N. Salleh, V. N. Ahmad, N. F. Kasim, S. M. Amri, and Y. S. Onn, "The effect of progesterone on uterine fluid ph \& endometrial nhe-1 protein expression in rats," Health, vol. 3, pp. 66-72, 2011.

[12] D. H. A. Maas, B. T. Storey, and L. Mastroianni, "Hydrogen ion and carbon dioxide content of the oviductal fluid of the rhesus monkey (Macaca mulatta)," Fertility and Sterility, vol. 28, no. 9, pp. 981-985, 1977.

[13] Q. He, H. Chen, C. H. Y. Wong, L. L. Tsang, and H. G. Chan, "Regulatory mechanism underlying cyclic changes in mouse uterine bicarbonate secretion: role of estrogen," Reproduction, vol. 140, no. 6, pp. 903-910, 2010.

[14] P. Karhumaa, S. Parkkila, O. Türeci et al., "Identification of carbonic anhydrase XII as the membrane isozyme expressed in the normal human endometrial epithelium," Molecular Human Reproduction, vol. 6, no. 1, pp. 68-74, 2000.

[15] X. F. Wang, M. K. Yu, S. Y. Lam et al., "Expression, immunolocalization, and functional activity of $\mathrm{Na}^{+} / \mathrm{H}^{+}$exchanger isoforms in mouse endometrial epithelium," Biology of Reproduction, vol. 68, no. 1, pp. 302-308, 2003.

[16] X. F. Wang, M. K. Yu, K. M. Leung et al., "Involvement of $\mathrm{Na}^{+}-\mathrm{HCO}_{3}{ }^{-}$cotransporter in mediating cyclic adenosine 3', $5^{\prime}$-monophosphate-dependent $\mathrm{HCO}_{3}$ - secretion by mouse endometrial epithelium," Biology of Reproduction, vol. 66, no. 6, pp. 1846-1852, 2002.

[17] X. F. Wang, C. X. Zhou, Q. X. Shi et al., "Involvement of CFTR in uterine bicarbonate secretion and the fertilizing capacity of sperm," Nature Cell Biology, vol. 5, no. 10, pp. 902-906, 2003.

[18] S. K. Fong, C. Q. Liu, and H. C. Chan, "Cellular mechanisms of adrenaline-stimulated anion secretion by the mouse endometrial epithelium," Biology of Reproduction, vol. 59, no. 6, pp. 1342-1348, 1998.

[19] H. C. Chan, Y. C. Ruan, Q. He et al., "The cystic fibrosis transmembrane conductance regulator in reproductive health and disease," Journal of Physiology, vol. 587, no. 10, pp. 2187-2195, 2009.

[20] Y. Liu, D. K. Wang, and L. M. Chen, "The physiology of bicarbonate transporters in mammalian reproduction," Biology of Reproduction, vol. 86, pp. 1-13, 2012.

[21] F. K. Marcondes, F. J. Bianchi, and A. P. Tanno, "Determination of the estrous cycle phases of rats: some helpful considerations," Brazilian Journal of Biology, vol. 62, no. 4, pp. 609-614, 2002.

[22] N. Salleh, D. L. Baines, R. J. Naftalin, and S. R. Milligan, "The hormonal control of uterine luminal fluid secretion and absorption," Journal of Membrane Biology, vol. 206, no. 1, pp. 17-28, 2005.

[23] L. Rochwerger and M. Buchwald, "Stimulation of the cystic fibrosis transmembrane regulator expression by estrogen in vivo," Endocrinology, vol. 133, no. 2, pp. 921-930, 1993.

[24] L. Rochwerger, S. Dho, L. Parker, J. K. Foskett, and M. Buchwald, "Estrogen-dependent expression of the cystic fibrosis transmembrane regulator gene in a novel uterine epithelial cell line," Journal of Cell Science, vol. 107, no. 9, pp. 2439-2448, 1994.

[25] A. Mularoni, L. Beck, R. Sadir, G. L. Adessi, and M. Nicollier, "Down-regulation by progesterone of CFTR expression in endometrial epithelial cells: a study by competitive RT-PCR," Biochemical and Biophysical Research Communications, vol. 217, no. 3, pp. 1105-1111, 1995.

[26] J. Z. Yang, L. C. Ajonuma, L. L. Tsang et al., "Differential expression and localization of CFTR and $\mathrm{ENaC}$ in mouse endometrium during pre-implantation," Cell Biology International, vol. 28, no. 6, pp. 433-439, 2004.

[27] T. Nobuzane, S. Tashiro, and Y. Kudo, "Morphologic effects of epithelial ion channels on the mouse uterus: differences between raloxifene analog (LY117018) and estradiol treatments," American Journal of Obstetrics and Gynecology, vol. 199, no. 4, pp. 363.e1-363.e6, 2008.

[28] I. Ben Abda, F. De Monbrison, N. Bousslimi, K. Aoun, A. Bouratbine, and S. Picot, "Advantages and limits of real-time PCR assay and PCR-restriction fragment length polymorphism for the identification of cutaneous Leishmania species 
in Tunisia," Transactions of the Royal Society of Tropical Medicine and Hygiene, vol. 105, no. 1, pp. 17-22, 2011.

[29] L. Chan, X. Wang, L. Tsang et al., "Inhibition of amiloridesensitive $\mathrm{Na}^{+}$absorption by activation of CFTR in mouse endometrial epithelium," Pflugers Archiv European Journal of Physiology, vol. 443, no. 1, supplement, pp. S132-S136, 2001.

[30] A. Smith, C. Contreras, H. K. Kwang et al., "Gender-specific protection of estrogen against gastric acid-induced duodenal injury: stimulation of duodenal mucosal bicarbonate secretion," Endocrinology, vol. 149, no. 9, pp. 4554-4566, 2008.

[31] B. Tuo, G. Wen, J. Wei et al., "Estrogen regulation of duodenal bicarbonate secretion and sex-specific protection of human duodenum," Gastroenterology, vol. 141, pp. 854-863, 2011.

[32] B. Tuo, G. Wen, and U. Seidler, "Differential activation of the $\mathrm{HCO}_{3}{ }^{-}$conductance through the cystic fibrosis transmembrane conductance regulator anion channel by genistein and forskolin in murine duodenum," British Journal of Pharmacology, vol. 158, no. 5, pp. 1313-1321, 2009. 

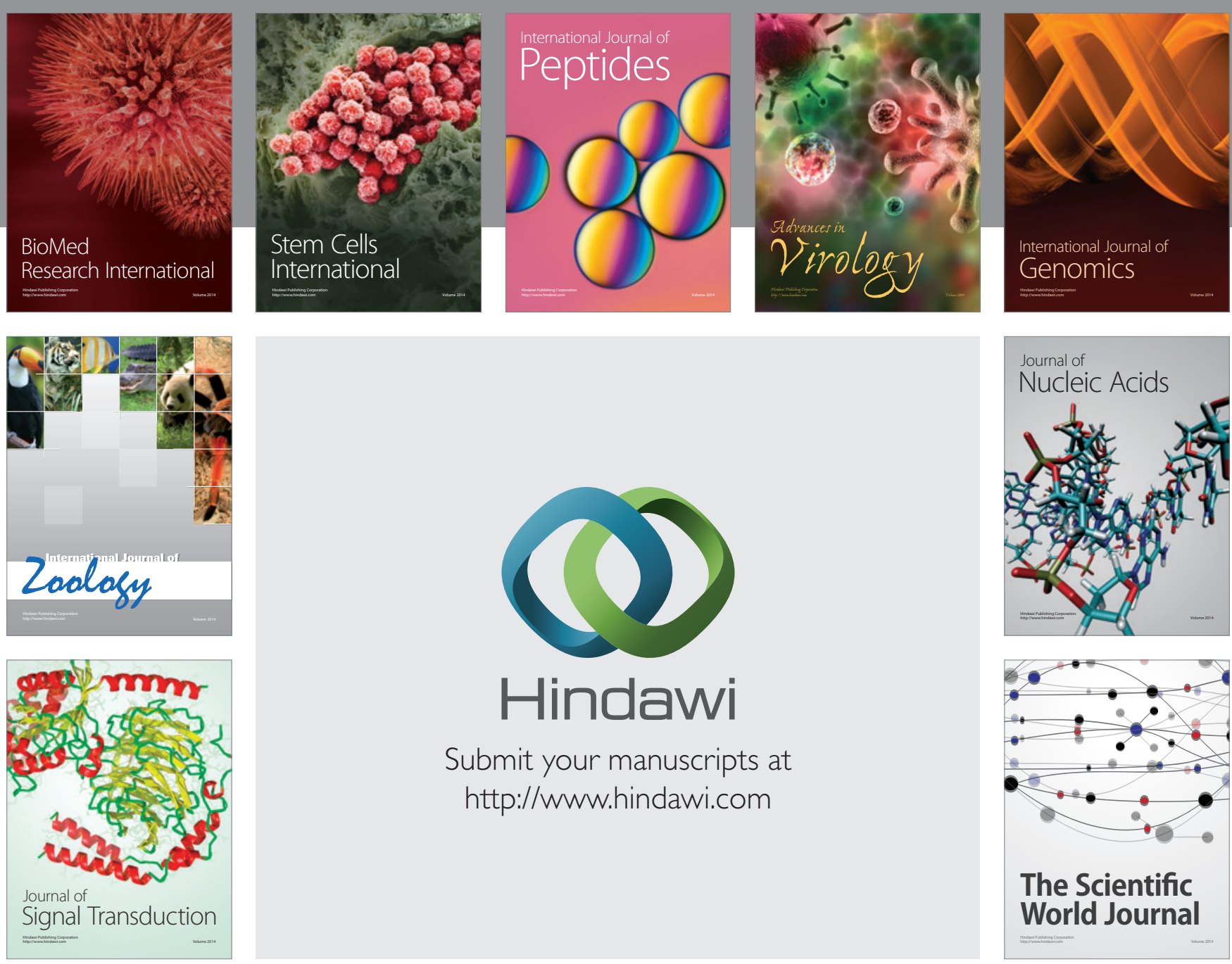

Submit your manuscripts at

http://www.hindawi.com
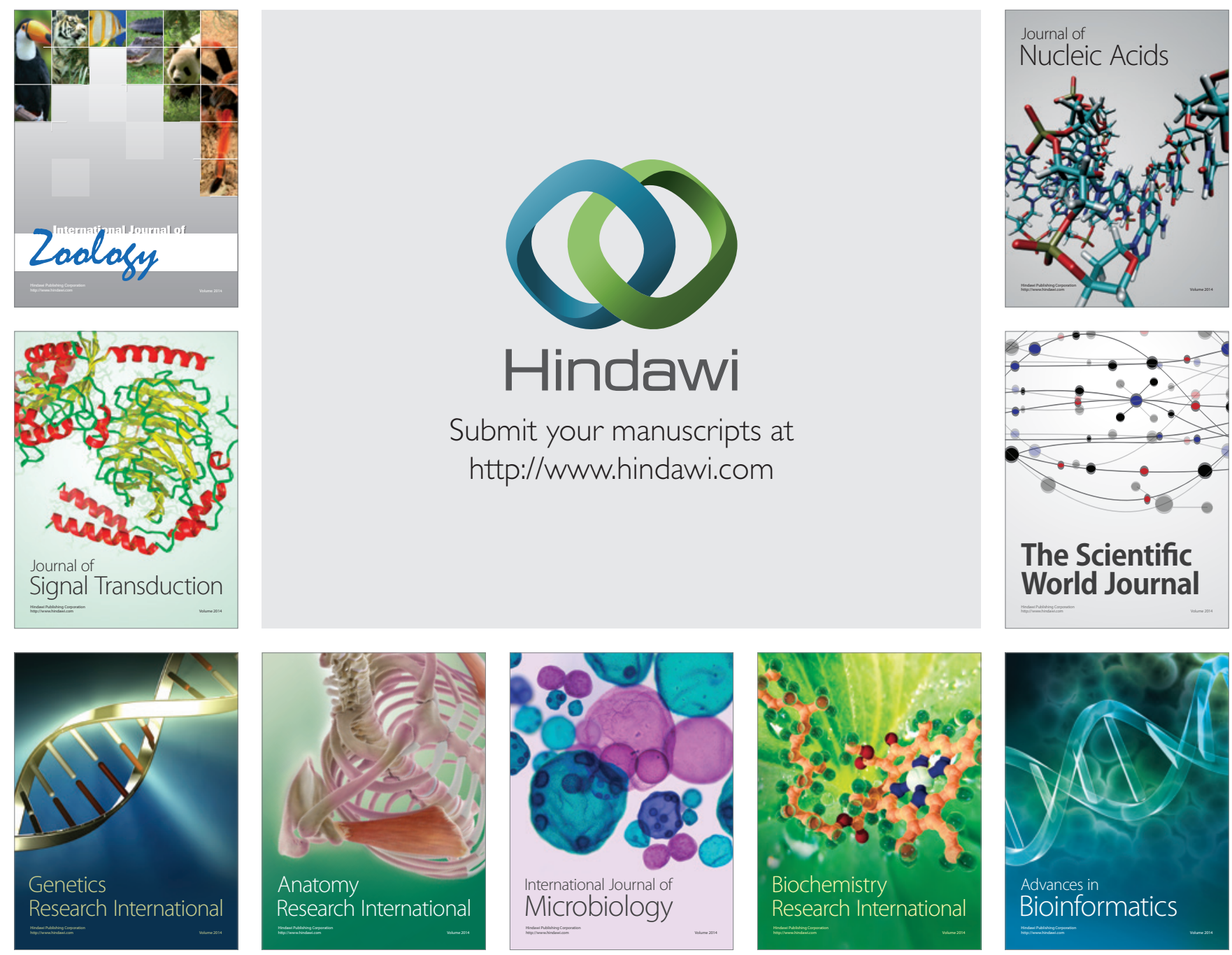

The Scientific World Journal
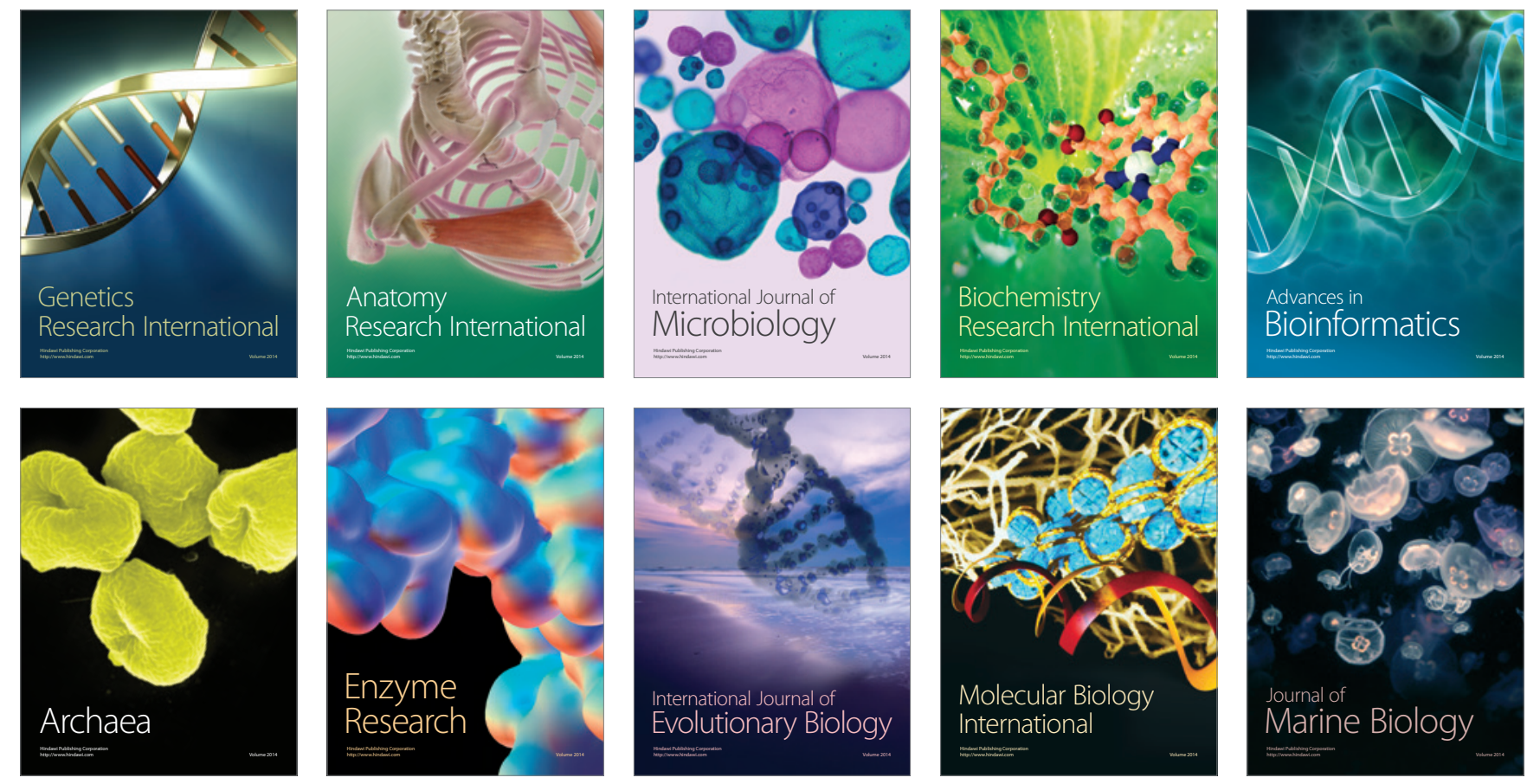